\title{
Космос в логосе: транслингвальная поэзия Эдуарда Мижита и Бахыта Каирбекова
}

\section{Ольга А. Валикова, Бакытгуль Е. Шагимгереева, Шекер А. Кулиева}

Российский университет дружбы народов, Российская Федерация
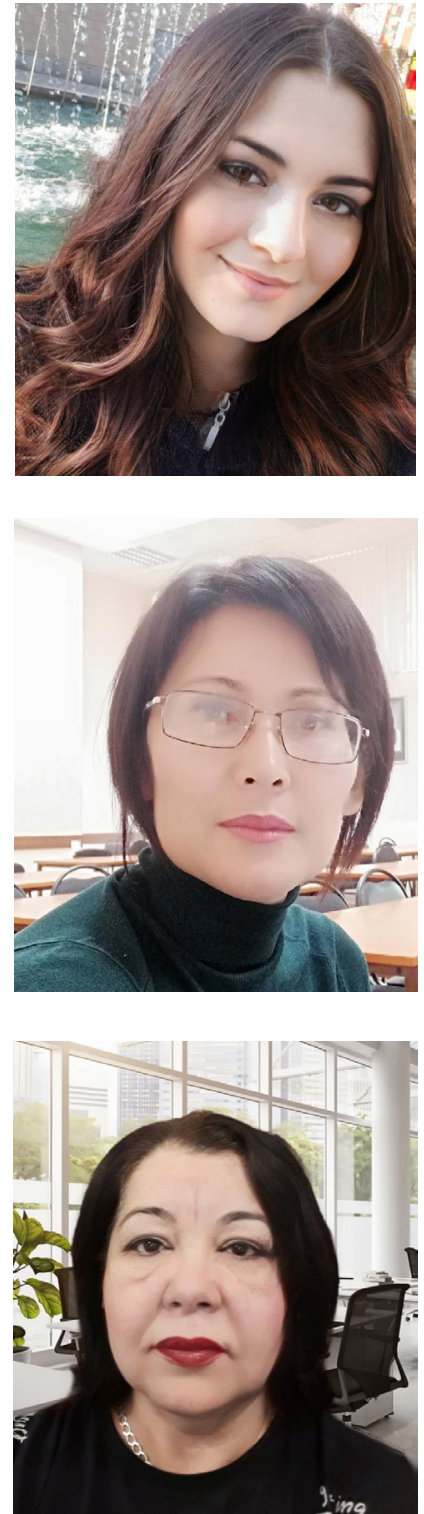

В статье рассматриваются вопросы художественного транслингвизма в его русско-тувинском и русско-казахском воплощении. Национальная литература, произрастающая из этногенетической «почвы» аутентичной культуры того или иного народа и оформленная на русском языке, в современной терминологии определяется как транслингвальная, русскоязычная и русофонная (У. М. Бахтикиреева). Несмотря на свое русскоязычное оформление, русофонный художественный текст продолжает транслировать во внешнее коммуникативное пространство национальные образы мира - первичные культурные коды (базисные концепты).

Авторы продемонстрировали это на поэтическом материале двух выдающихся поэтов современности - тувинца Эдуарда Мижита и казаха Бахыта Каирбекова. Рассматривались русскоязычные поэтические тексты Э. Мижита (циклы «Глас тишины», «Капли вечности», «Корни», «Грани одиночества», «Минутное», «Сквозь себя», «Бездна», «Бусинки столетий» и др.) и Б. Каирбекова («За решеткой слов», «Таинственные праздники», «Против солнцая», «Части цеелого»).

Обоим поэтам свойственна тональность размышления, выраженная в соответствующих жанрах: ожук дажы (классическое тувинское трехстишие) и толгау (жанр казахской литературы, созерцание-размышление). Для обоих представителей своей литературы важна особая, полищентрическая организация хронотопа и выраженное пантеистическое миросозерцание, обусловленное сплавом религиозных и мировоззренческих парадигм (от шаманизма до буддизма, от тенгрианства до анимизма). В обоих поэтических универсумах лирический герой - одинокий странник в поисках Истины, актуализированный в мифологемах Охотника и Номада, Баксы и Батыра.

Ключевые слова: транслингвизм; русскоязычная литература; тувинская поэзия; казахская поэзия; Эдуард Мижит; Бахытт Каирбеков
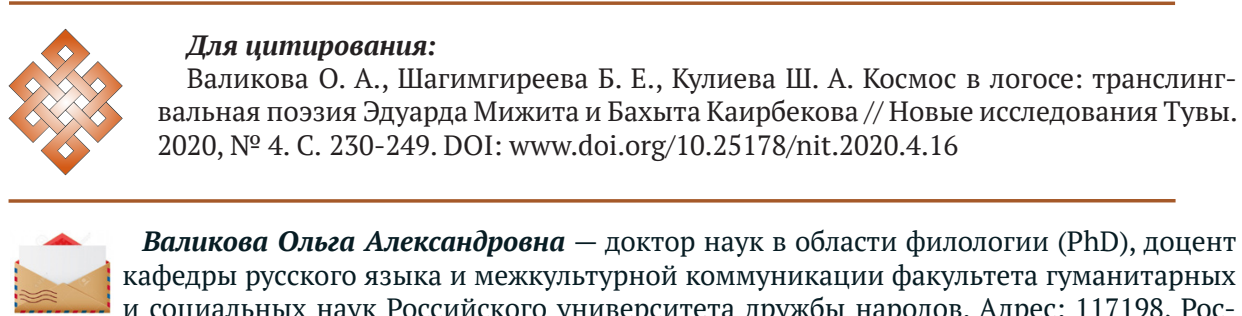

Валикова Ольга Александровна - доктор наук в области филологии $(\mathrm{PhD})$, доцент кафедры русского языка и межкультурной коммуникации факультета гуманитарных и социальных наук Российского университета дружбы народов. Адрес: 117198 , Российская Федерация, г. Москва, ул. Миклухо-Маклая, д. 10. Тел.: +7 (495) 787-38-03. Эл. адрес: leka.valikova@mail.ru

Шагимгереева Бакытгуль Ерсаиновна - аспирант кафедры общего и русского языкознания филологического факультета Российского университета дружбы народов. Адрес: 117198, Российская Федерация, г. Москва, ул. Миклухо-Маклая, д. 10. Тел.: +7 (495) 434-37-45. Эл. адрес: t_2004@mail.ru

Кулиева Шекер Авдыевна - кандидат исторических наук, доцент кафедры иностранных языков факультета гуманитарных и социальных наук Российского университета дружбы народов. Адрес: 117198 , Российская Федерация, г. Москва, ул. Миклухо-Маклая, д. 10. Тел.: +7 (495) 787-38-03. Эл. адрес: shekkul@mail.ru

VALIKOVA, Olga Alexandrovna, PhD in Philology, Associate Professor, Department of Russian Language and Intercultural Communication, Faculty of Humanities and Social Sciences, Peoples' Friendship University of Russia (RUDN University). Postal address: 10 Miklukho-Maklaya St., 117198 Moscow, Russian Federation. Tel.: +7 (495) 787-38-03. E-mail: leka.valikova@mail.ru

SHAGIMGEREYEVA, Bakytgul Ersainovna, Postgraduate Student, Department of General and Russian Linguistics, Philological Faculty, Peoples' Friendship University of Russia (RUDN University). Postal address: 10 Miklukho-Maklaya St., 117198 Moscow, Russian Federation. Tel.: +7 (495) 434-37-45.E-mail: t_2004@mail.ru

KULIEVA, Sheker Avdyevna, Candidate of History, Associate Professor, Department of Foreign Languages, Faculty of Humanities and Social Sciences, Peoples' Friendship University of Russia (RUDN University). Postal address: 10 Miklukho-Maklaya St., 117198 Moscow, Russian Federation. Tel.: +7 (495) 787-38-03. E-mail: shekkul@mail.ru ORCID ID: 0000-0001-8682-0891 


\title{
Cosmos in Logos: Translingual Poetry by Eduard Mizhit and Bakhyt Kairbekov
}

\author{
Olga A. Valikova, Bakytgul E. Shagimgereeva, Sheker A. Kulieva
}

Peoples' Friendship University of Russia, Russian Federation

\begin{abstract}
This article examines the issues of literary translingualism in its Russian-Tuvan and Russian-Kazakh representations. National literatures, which are sustained by the ethnogenetic "soil" of the authentic culture of an ethnic group, can be described in modern terminology as translingual, Russian-speaking and Russophonic (U. M. Bakhtikireeva). Although its external form is indeed Russophonic, the literary text keeps transmitting into the external communicative space primary cultural codes (basic concepts), which are elements of the national world picture.

The article demonstrates this, using the case of poetry by two outstanding poets of the present times - Eduard Mizhit, a Tuvan and Bakhyt Kairbekov, a Kazakh. We focus on such Russian-language poetic texts by E. Mizhit as his collections "The Voice of Silence", "The Drops of Eternity”, "Roots”, "Facets of Loneliness", "The Transient", "Through Oneself”, "The Abyss", and "Beads of Centuries", and B. Kairbekov's "Behind the Lattice of Words", "Mysterious Holidays", "Against the Sun", and "Parts of the Whole".

Both poets share a reflective tone which finds its expression in specific genres: ozhuk dazhy (a classic Tuvan three-liner) and tolgau (a genre of Kazakh literature combining contemplation and reflection). A special polycentric organization of space and time is also shared by both poets, as well as a pantheistic outlook, conditioned by the fusion of religious and worldview paradigms (from shamanism to Buddhism, from Tengrism to animism), is also important. A lyrical hero in both poetic universes is a lonely wanderer in a search of Truth, who takes on cultural masks of the Hunter and Nomad, of Baksa and Batyr.
\end{abstract}

Keywords: translingualism; Russian-language literature; Tuvan poetry; Kazakh poetry; Eduard Mizhit; Bakhyt Kairbekov

\section{For citation:}

Valikova O. A., Shagimgereeva and Kulieva Sh. A. Kosmos v logose: translingval'naia poeziia Eduarda Mizhita i Bakhyta Kairbekova [Cosmos in Logos: Translingual Poetry by Eduard Mizhit and Bakhyt Kairbekov]. New Research of Tuva, 2020, no. 4, pp. 230-249. (In Russ.). DOI: www.doi.org/10.25178/nit.2020.4.16

\section{Введение}

Цель настоящей статьи - попытка осмысления феномена транслингвизма (и русскоязычия как его варианта) на материале отдельных поэтических текстов тувинца Э. Мижита и казаха Б. Каирбекова, написанных на русском языке. Мы попытаемся показать, как в семиотической сложности художественного текста, созданного на русском языке этнически нерусскими авторами, взаимодействуют различные культурные коды, генерируя новую эстетическую реальность - культурно усложненную и в определенном смысле уникальную.

В приведенной работе мы опираемся на результаты современных исследователей транслингвизма, в частности, С. Келлмана (Kellman, 2003), М. Танненбаума (Tannenbaum, Haim, 2007), Дж. Хансен (Transcultural identities ... , 2013), С. Канагараджа (Канагараджа, 2016) О. Гарсиа, Л. Вей (Garcia, Wei, 2014), М. Тлостановой (Тлостанова, 2004), 3. Г. Прошиной (Прошина, 2017), И. С. Хугаева (Хугаев, 2008), однако магистральным направлением поиска считаем траекторию, эпистемологически заданную У. М. Бахтикиреевой (Бахтикиреева, 2009). В соответствии с установками У. М. Бахтикиреевой, русскоязычие следует рассматривать как уникальную ситуацию онтоязыкового порядка, характерную для советского и постсоветского периода. Внутри нее происходит контаминация множественных образов мира, объективированная средствами русского языка в пределах художественного текста.

Методологическую базу исследования составили также статьи и теоретические работы литературоведов, посвященные осмыслению творчества Э. Мижита и Б. Каирбекова в контексте современного 
литературного процесса: Л. С. Дампиловой (Дампилова, 2014, 2015), У. А. Донгак (Донгак, 2020), Л. С. Мижит (Мижит, 2007), А. М. Соян (Соян, 2018), М. А. Хадаханэํㅗ В. В. Бадикова (Бадиков, 2003), Н. О. Джуанышбекова (Джуанышбеков, 2010), Н. М. Томановой (Томанова, 2012), М. Сомадая (Сомадай, 2014), Е. Н. Кремер (Кремер, 2010).

Материалом исследования послужили избранные стихотворения Э. Мижита и Б. Каирбекова, в которых репрезентирована внутренняя форма национальной культуры. Мы обратились к таким произведениям Мижита, как «Мысль», «Мой одинокий зов», «Спасение»², циклам «Бусинки столетий» и «Время моей земли» ${ }^{3}$. Стихотворения Б. Каирбекова «Когда в степи моей умолкнут кузнечики», «Все встало на свои места», «Перевозчик», «Асатаяк», «Если сердце твое кровоточит» ${ }^{4}$, «ся эта даль бескрайняя в степях», «Степь - многотравный простор ${ }^{5}$ также составили базу нашего исследования.

\section{Транслингвизм: вводные замечания}

Кризис «конца локальности», о котором рассуждают современные философы (Тлостанова, 2004), индуцирует переход мыслящих субъектов эпохи постмодерна в «пространство вненаходимости», внедомности, «культурной ловушки». Это ощущение можно описать формулой «ни тут, ни там», когда личность занимает промежуточное положение на «перекрестке культур», не входя ни в одну из них как в среду своего обитания. Это «транс» шаманского камлания, поиск Автором новых способов восприятия мира в Хаосмосе (Лейдерман, 2005) современности, когда субъект литературы «привык жить вне локальностей, но его бессознательное по-прежнему полно осколков прошлого» (Тлостанова, 2004: 47). Вместе с тем складывается и противоположная тенденция (в мировой литературе выраженная, однако, менее интенсивно) - онтоязыковое ощущение «и тут, и там», при котором элементы нескольких культур участвуют в процессе сотворения нового жизненного пространства творческой личности.

Литературу, создаваемую писателями на неродном для них языке, называют транскультурной (в широком смысле) или транслингвальной. Как отмечает М. Танненбаум (M. Tannenbaum), «транслингвальная литература, раскрывающая сущность творчества поэтов и писателей, пишущих на языке, который не является для них «материнским», предъявляет увлекательное место встречи таких понятий, как язык, иммиграция и идеология» (Tannenbaum, Haim, 2007: 273; перевод наш. - Aвт.).

Транслингвальная литература, существующая со времен «мифического Вавилона» (Kellman, 2019), обрела в третьем тысячелетии невиданный размах. Острые дискуссии возникают при оценке этого феномена. С одной стороны, транслингвальная литература способна расширить наш «горизонт понимания», а, значит, и горизонт толерантности. «Художественная литература предлагает мощные средства для изучения транскультурного опыта и решения проблем, которые она ставит как перед отдельными людьми, так и перед всем обществом. Сам акт чтения литературных текстов потенциально является транскультурным опытом, поскольку предлагает читателю отождествить себя с перспективами вымышленных героев из незнакомых географических мест» (Transcultural identities ..., 2013: 10; перевод наш. - Авт.). С другой стороны, доминирующий язык зачастую воспринимается как «среда порабощения», развернутый «знак» до конца не изжившей себя колониальности. Следует признать, что транслингвизм всегда подразумевает прагматическое доминирование одного языка над другим, обусловленное разными причинами: желанием писателя создать широкую диалоговую площадку с читателем (ведь Esse est percipi); наличием в другой языковой системе более совершенного арсенала изобразительных средств и техник, ожидание коммерческого успеха и т. п. Но значит ли это, что транслингвизм следует оценивать негативно?

Как полагает апологет русофонной литературы на постсоветском пространстве У. М. Бахтикиреева (Бахтикиреева, 2009), художественное трансъязычие - практика, благодаря которой достигается стереоскопичность зрения и то свойство мышления, которое можно охарактеризовать как радиантное. В русофонной литературе (как одной из моделей литературы транслингвальной) исследователь видит диалог различных мировоззрений, благодаря которому генерируется новое, более сложное в

Хадаханэ М. А. Странный поэт Мижит // Тувинская правда. 1994. 6 янв. С. 4.

Мижит Э. Расколотый миг. Кызыл : Тувинское книжное издательство, 2011. 122 с.

Мижит Э. Время моей земли [Электронный ресурс] // Сибирские огни. 2006. № 4. http://сибирскиеогни.рф/ content/vremya-moey-zemli (дата обращения: 12.08.2020).

Каирбеков Б. Дневник. Алматы : Интерпринт, 2003. 224 с.

Каирбеков Б. Навстречу солнцу. Дневник путешествий. Статьи, эссе. Алматы: Нуракынов, 2014. 420 с. 
онтологическом и художественном плане смысловое пространство, внутри которого циркулируют элементы гетерогенных лингвокультурных сфер. Благодаря русскому языку как широкому каналу доступа читатель получает возможность приобщиться к новой для себя картине мира, объективированной в художественном тексте, и в этом случае русскоязычие выполняет функцию коммуникативного моста к неисчерпаемым культурным ресурсам народов постсоветского пространства (Bakhtikireeva, Valikova, King, 2017: 166). Исследователь рассматривает транслингвальный художественный текст как полилингвиальный феномен, то есть семиотически усложненное, многокодовое единство, внутри которого взаимодействуют «языки» разного уровня сложности, в том числе языки визуальные и аудиальные. В пространстве же вербального комплекса художественного целого происходит синергетическое взаимодействие культур, результатом которого становится «встреча энергий»лингвокреативного потенциала каждого лингвокультурного поля.

Симптоматично, что многие постсоветские авторы определяют свой контекст существования как «континуум нескольких языков и культур», указывая, скорее, на межкультурный синтез, а не на разделение литературы на «этнодома». Показательны и их самоопределения: «номад семиотических пространств» (А. Жаксылыков), «медиатор» (О. Сулейменов), «рот, вмещающий два языка» (Е. Зейферт $)^{1}$. Каждая культура в процессе взаимодействия сохраняет за собой право на собственную аутентичность, «непрозрачность». Транскультурация не предполагает стирания границ между этносами. Она прокладывает коммуникативный мост через культурные фронтиры, соединяя территориально, этнически, лингвально отдаленные друг от друга культуры и обеспечивая транспортацию разнообразных культурных элементов из одного семиотического пространства в другое. В результате этого двунаправленного процесса культурный ландшафт обоих пространств видоизменяется. В условиях гетерогенного по своему составу мирового общества транскультурация видится одной из наиболее продуктивных стратегий этнокультурного «самосохранения».

М. Тлостанова справедливо подчеркивает, что транскультурация бросает вызов монокультурной природе конструкта «нация-государство», апеллирующего к мифической идее «чистой культурной идентичности, не зараженной гибридизацией» (Тлостанова, 2006: 134). Как отмечает С. Канагараджа, «эта идеология языковой чистоты и автономии противоречит повседневной практике, когда языки находятся в постоянном контакте и смешиваются, порождая новые грамматики и новые значения. Общаясь, люди берут, что им нужно, из разных кодов и семиотических ресурсов, не ограничиваясь знаками одного языка (Канагараджа, 2016:16).

Характерный пример несовпадения этноса и языка - феномен русскоязычия на территории сначала Российской Империи, а затем советского и постсоветского пространства.

Как отмечает У. М. Бахтикиреева, в 20-х годах XX века сформировалась единая культурно-историческая область, включавшая в себя Россию, Украину, Белоруссию, Молдавию, Прибалтику (Латвию, Литву, Эстонию), Закавказье (Азербайджан, Армению, Грузию), Центральную Азию (Казахстан, Киргизию) и Среднюю Азию (Таджикистан, Туркмению, Узбекистан). Этническая и языковая личности большинства жителей СССР не совпадали, так как усвоение другого языка вовсе не ведет к усвоению другой культуры (по крайней мере, для подобного явления необходим существенный временной период) (Бахтикиреева, 2009).

Процессу литературной транслингвации предшествовало масштабное явление коллективного билингвизма, обусловленное как прагматическими, так и психическими причинами. Под билингвизмом принято понимать «владение двумя языками, как родными», «практику попеременного пользования двумя языками» (Вайнрайх, 1979: 22). Билингвизм как использование языковой пары «русский язык - не-русский язык» варьировался в зависимости от территории бытования: вторым членом приведенной диады мог быть тувинский, казахский, киргизский и любой другой язык-репрезентант, входящий в «языковую мозаику» СССР. Повсеместный литературный процесс на усвоенном русском языке - показательный пример транслингвальной творческой практики этнически нерусских авторов. По мнению О. Гарсия и Ли Вей, в понятиях «транслингвальная деятельность» и «транслингвальная практика» заложена идея лингвистической креативности писателей-билингвов (Garcia, Wei, 2014).

Актуальность термина «транслингвизм» сигнализирует о новом качестве текстов (в том числе художественных), которые нельзя обозначить ни как «билингвальные», ни как собственно «моно-

\footnotetext{
${ }^{1}$ Из личной беседы О.А. Валиковой с указанными авторами: А. Ж. Жаксылыковым (сентябрь 2016 г.), О. О. Су-
} лейменовым (декабрь 2017 г.), Е. И. Зейферт (март 2018 г.). 
язычные». Транслингвальный текст подразумевает отсутствие четких границ между контактирующими языками и определенную интеграцию языковых ресурсов внутри художественного целого. Некоторые исследователи (Туманова, 2010) говорят о контаминации различных языковых картин мира в пределах художественного текста. Другие указывают на внутреннее перераспределение языковых элементов, образующих языковой континуум. Таким образом, в распоряжении автора-билингва оказывается ресурсная база двух языков.

Русский язык перестал совпадать только с русской языковой культурой как в геолингвистическом, так и в культурно-духовном аспекте. Но остается ли в этом случае язык «духом народа»? И, если да, то какого именно народа? Утрачивается ли этническая культура из-за функционального перехода к другому языку?

Очевидно, что не утрачивается. Более того - через посредство языка, наделенного большими функциональными «полномочиями», этническая культура транслируется во внешнее перцептивное пространство, т. е. расширяет территорию своей экзистенции. И. С. Хугаев говорит в этом случае о наличии «этнического субстрата» (Хугаев, 2008) в русскоязычных художественных текстах, М. Тлостанова указывает на «мерцающую внутреннюю форму произведения» (Тлостанова, 2004). Язык (в нашем случае - русский) выступает здесь «единящим началом» (формулировка М. Хайдеггера). Говоря через автора-транслингва, язык не может не выражать его (говорящего, пишущего) этническую самость, не может не преломляться сквозь его этническое самосознание (хотя, как справедливо отмечает Л. С. Дампилова, далеко не все русскоязычные тексты писателей-билингвов «национальноколоритны»: зачастую они непрозрачны, лингвистически нейтральны, и квалифицировать их как свидетельства «иноязыкового бытия» затруднительно) (Дампилова, 2015: 197).

Транслингвальный автор - это человек семиотического «пограничья» (неслучайно Б. Каирбеков определяет себя как мифического «перевозчика»), посредник между культурами, а транслингвальный текст - своеобразный кроссовер, вбирающий в себя черты нескольких культур, но не соответствующий ни одной из них полностью.

Каждый этнос на протяжении веков формирует свои инвариантные «образы мира», детерминированные особенностями форм существования, национальной культуры и психологии. Эти образы одновременно коллективны и индивидуальны, осознанны и бессознательны. Именно они структурируют впоследствии вербализованное знание.

\section{О поэтическом творчестве Э. Мижита и Б. Каирбекова}

Обратимся к поэтическому творчеству двух выдающихся поэтов современности - тувинца Эдуарда Мижита (1961 г. р.) и казаха Бахыта Каирбекова (1953 г. р.). Оба этих имени являются знаковыми для тувинской и казахстанской литературы.

Будучи представителями своей этнокультуры, оба писателя прошли «школу русского слова», окончив Литературный институт им. М. Горького (Э. Мижит в 1993 г., Б. Каирбеков - в 1975 г.). Оба в совершенстве овладели интермедиальными формами искусства: Э. Мижит - выдающийся драматург, Б. Каирбеков - талантливый кинорежиссер. Стоит отметить, что подобная интермедиальность не могла не сказаться на языковой экспрессии поэтического языка каждого из авторов. Так, уникальный драматический талант Э. Мижита проявлен в его философских миниатюрах, когда лирический субъект стихотворения «раздваивается», метафизически расщепляется, и между частями «Я» и «Я-Другого» нарастает существенное напряжение, требующее разрешения и ведущее к катарсису (см., например, стихотворения цикла «Грани одиночества»). Многие стихотворения Б. Каирбекова - визуальны, «кинематографичны»: это стоп-кадры запечатленных в памяти событий, испытанных эмоций, зримо-явственных картин воображения и восприятия («Акведук над рекой./ Стволы берез./ И листьев увяданье.../ Фотообои - / Окно в застывший мир. / Но не раскрыть окна, / В реке не искупаться. / Все время осень).

Оба поэта сумели воссоздать космологию родной культуры в русскоязычном слове (Э. Мижит - писатель-билингв, создающий свои произведения как на тувинском, так и на русском языках; Б. Каирбеков, безукоризненно владеющий казахским языком, творит преимущественно на русском). Каждый смог обратить художественный ресурс русскоязычия на благо родной культуры: художественные тексты (в том числе тексты полилингвиальные, затрагивающие семиотические системы разного генезиса на уровне комбинаторики вербального, визуального, аудиального кодов) Э. Мижита и Б. Каирбекова вместилища национальных образов мира, культурных архетипов, устойчивых этноспецифических 
мотивов, ретранслируемых в поэтическом слове. Поэтическое творчество не ограничивается ретрансляцией культурных кодов; как справедливо подчеркивает У. М. Бахтикиреева, автор, избирающий русскоязычие одной из форм своего онтоязыкового бытия, генерирует новое знание о мире, производит новые смыслы, способствует трансформации воспринимающей его аудитории (Бахтикиреева, Шагимгереева, 2020: 88).

По мнению известного исследователя тувинской литературы У. А. Донгак, Э. Мижит (фото 1) - знаковое явление в современной культурной жизни Тувы (Донгак, 2020). Его формирование как поэта приходится на перестроечную эпоху; в постперестроечное и новейшее время тувинской литературы писатель достигает поэтической зрелости, о чем свидетельствуют публикации в «Антологии русского верлибра» (1991), сборниках верлибров на тувинском и русском языках (Бузундулар (Осколки), 1992; Расколотый миг, 2011), в сборнике стихов в прозе «Казыргылыг кудуктуң кыйгызы» (Зов взвихренного колодца, 2002). По мнению У. А. Донгак, поэт осмысливает образы и сюжеты мировой художественной культуры в контексте тувинской эстетики, что позволяет говорить о новаторской линии его творчества (Донгак, 2020).

Биография писателя насыщенна; его творческая актив-

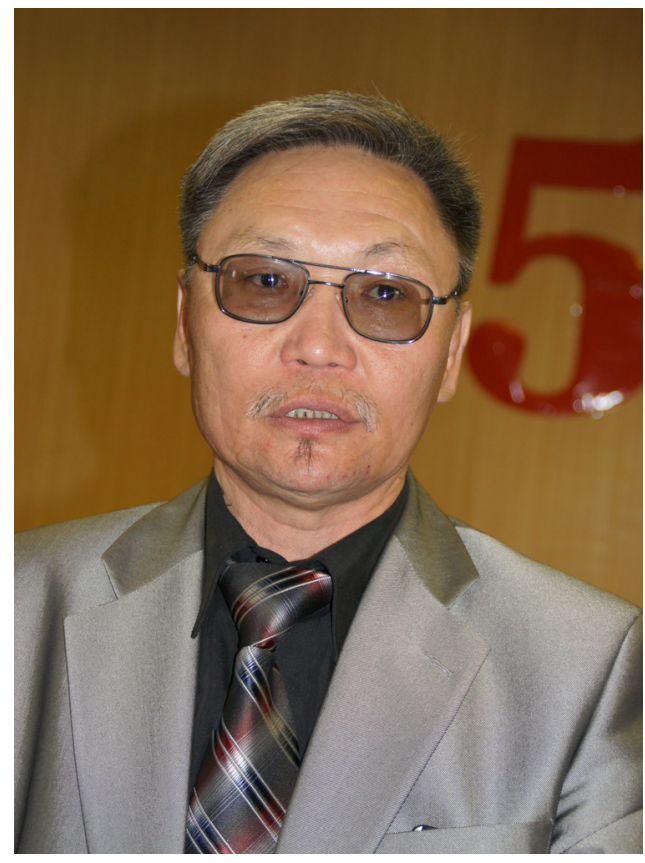

Фото 1. Эдуард Мижит.

Фото из семейного архива Э. и Л. Мижит. Photo 1. Eduard Mizhit. Photo from the family archive of E. and L. Mizhit. ность сопряжена с различными видами социальной деятельности. Э. Мижит служил в армии, трудился воспитателем, работал санитаром в психбольнице, был сторожем и учителем. Это «открывание жизни» (Ф. М. Достоевский) существенным образом сказалось на его идиостиле, как справедливо подчеркивает Л. С. Дампилова (Дампилова, 2014: 158). Художественный метод поэта обогатился «эмпирическим материалом», в результате чего произошло взаимоналожение двух уровней личной истории: жизни человека «внешнего» и жизни человека «внутреннего». Исследователи творчества Э. Мижита, в частности, Ш. Монгуш и Л. С. Мижит, отмечают в произведениях автора наличие «скрытого течения» (чажыт агым), имплицитных смыслов, требующих от читателя не только определенных интеллектуальных усилий, но и готовности к со-творчеству, соразмышлению.

По мнению У. А. Донгак, Э. Мижит ввел в тувинскую поэзию модус самосознания («Я понял вдруг, что существую...») (Донгак, 2020: 466). А. Л. Кошелева, исследующая категории времени, пространства и Человека в поэме Э. Мижита «Пируэты мысли» (2012), отмечает, что Поэт и его Мысль слиты воедино в сущности авторского «эго», вечноголодного в своем стремлении осознать собственное место в мире. Мысль кристаллизуется в Творчестве, которое есть попытка понять Творца и его Творение путем сотворения собственных смыслов, образов, ритмов. Творчество для Мижита, как пишет А. Л. Кошелева, это познание «Древа Жизни, Древа тайны Творения и Бытия-во-времени» (Кошелева, 2016: 22).

Поэзия Э. Мижита диалогична, открыта читательской рецепции, философична. Его поэтические тексты отличаются палимпсестной структурой. Они многослойны: за каждым из «слоев» художественного текста стоит сложная система культурных кодов и философем, совокупность которых способна дать читателю представление о широте метафизического горизонта автора. Поэт стремится к Гармонии всего сущего. Все явления жизни, все приметы, предметы, детали «вещного» мира в поэтике Э. Мижита связаны с сокровенным бытием души, сложным и непостижимым, как Тайна. Лирика поэта - творческая реакция на сократовский императив «Познай самого себя». В этом плане оно близко интенциям и художественным поискам Б. Каирбекова.

Становление языковой биографии Б. Каирбекова (фото 2), как пишут У. М. Бахтикиреева и Б. Е. Шагимгереева, «начинается в особый период языкового строительства СССР - гомогенизации единой культурно-исторической общности - советский народ. Для реализации нерусского среднестатистического советского гражданина в конкретную личность жизненно необходимым становится высокий уровень владения русским языком. И Бахыт овладевает этим языком на высоком уровне, так, что доминирующий в его языковом сознании - русский - становится языком творчества, 


\section{НОВЫЕ ИССЛЕДОВАНИЯ ТУВЫ}

www.nit.tuva.asia

№4

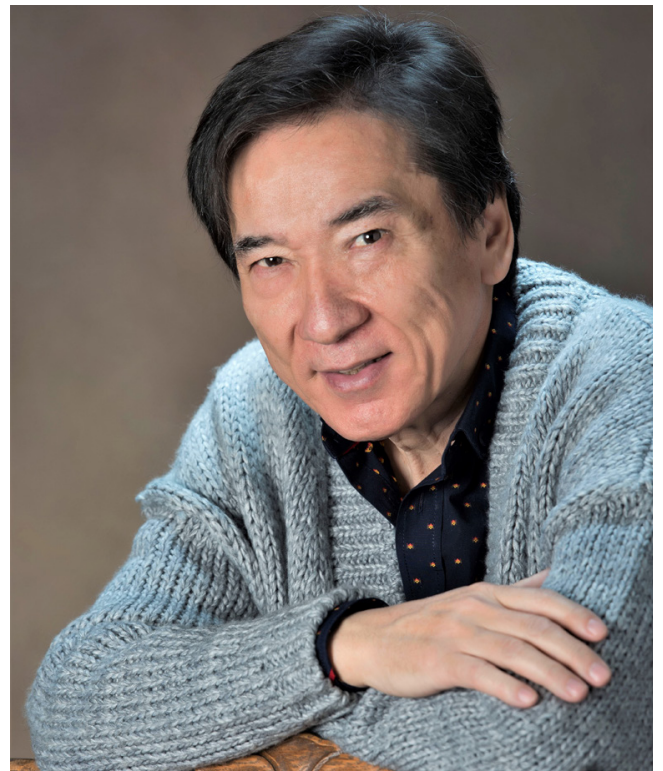

Фото 2. Бахыт Каирбеков.

Фото Олега Белялова, 10 января 2018 г.

Фото из личного архива Б. Каирбекова.

Photo 2. Bakhyt Kairbekov. January 10, 2018.

Photo by Oleg Belyalov from the personal archive of B. Kairbekov.
THE NEW RESEARCH OF TUVA

2020

Novye issledovaniia Tuvy

отражения окружающей действительности и мировоззрения» (Бахтикиреева, Шагимгереева, 2020: 85).

Как отмечает В. В. Бадиков, стихотворения Б. Каирбекова можно определить как «лирические миниатюры»: они отличаются емкостью, афористичностью, интеллектуальной насыщенностью. Поэт наследует традиции Абая, Басё, Такубоку, Превера, но творчески преображает их в «лирическом сгустке» стиха, зачастую написанного как послание другу: предельно откровенно, благожелательно, искренне. Благодаря своей интимной тональности стихи Каирбекова напоминают дневник, одновременно исповедь и творческую лабораторию. Это никогда не зарисовки «на злобу дня», но всегда - «стенография души» (Бадиков, 2003: 4).

«Беспощадное вопрошание к себе, глубокое и обостренное чувство ответственности перед своим народом, его историей, культурой и перспективами обусловили важное жизненное решение, программу дальнейшей созидающей деятельности Б. Каирбекова. Он хочет “обогреться у очага своей культуры”, создавая космо-психо-логос Великой Степи в русской “языковой оболочке” (Бахтикиреева, Шагимгереева, 2020: 86).

Показательно, что оба поэта обращаются в своих произведениях к мотивам, свойственным культурам центрально-азиатского региона: степи, солнца, цикличности времени.

\section{Жанровая специфика. Тема Поэта и Поэзии}

В Космос национальной культуры мы входим в том числе через Логос - упорядочивающую силу языка, овеществляющего мир. Когда в русскоязычном тексте кристаллизуется картина мира «иноязыкового бытия», запечатленная в этноспецифическом жанре - например, жанре ожук дажы (тув. «камни очага», см. далее) - меняется сама «амальгама» реальности, предстающая воспринимающему сознанию читателя.

Э. Мижит привносит в эстетику своей тувино- и русскоязычной поэзии особую архитектоническую форму выражения - усложненную форму ожук дажы. Как отмечает Л. С. Мижит, жанр ожук дажы, реактивированный в тувинской поэзии в 80-х годах XX века, восходит к древней традиции трехстишия, характерной как для тувинской, так и для тюркской поэзии (Мижит, 2007).

Исследователь связывает генезис указанного жанра с феноменом триединства, заложенного в основы религиозно-мифологических представлений и традиционного мировоззрения тувинцев, и подчеркивает его динамическое воздействие на современный литературный процесс. Жанр ожук дажы как «формула добытой эстетической истины» репрезентируеттриединую космическую модель мироздания, в которой три уровня Вселенной (Верхний Мир - Срединный мир - Нижний мир) связаны с несущей, стержневой осью опорного шеста юрты как микрокосма (багана) и заложенного у его основании очага (ожук). Вертикаль мира пронизывает космические зоны Вселенной и самого человека, пребывающего одновременно в трех мирах. С космологической триадой, по мнению Л. С. Мижит, связан и феномен шаманизма: шаман как медиатор между мирами способен перемещаться через границы трех сакральных пространств. «В структуре ожук дажы три строки ассоциируются с тремя камнями очага. Конечно, данная поэтическая форма легко воспринимаема и до конца понятна именно носителю той культуры, на почве которой она возникла. Три камня очага - символ традиционного образа жизни и культуры кочевника, образ мироздания в виде триединства. Три камня, служившие вместо треножника, вызывали чувство устойчивости, крепости и покоя у кочевников-скотоводов. Известно, что у древних тюрков тоже был очаг из трех камней, безусловно, придававших огромную внутреннюю, духовную силу древним воинам, которые, глядя на очаг, под синим небом, чувствовали свое единство с Природой, Родиной, народом. На наш взгляд, эта поэтическая форма соответствует природе и духу кочевников Центральной Азии» (там же: 9). Поэтика ожук дажы направлена на интенсификацию смысла, когда каждая последующая строка углубляет мысль и ведет к лаконичному выводу, зачастую - афористичной сентенции, которую можно рассматривать как эссенцию художественного целого. 
Э. Мижит создает новую форму ожук дажы - Улуг ожук дажы, представляющий собой «нанизывание» трехстиший в многокомпонентной строфической организации стихотворения. В соотнесенности строф рождается единство поэтики целого, его говорящая «внутренняя» форма. Э. Мижит привносит в тувинскую поэзию не только глубокое философское содержание, но и драматическую модусность: драматизм как эстетическая доминанта, по мнению В. С. Тюпы, синкретизирован с элегическим и идиллическим тонами повествования (Тюпа, 2012).

Смыслопорождающей энергией драматизма становится энергия страдания и со-страдания, в основе которого лежит осознание героем своего места в мире. При этом определяющее значение для драматического модуса несет фигура Другого (иного «Я»), в присутствии которого раскрывается одиночество лирического героя как способ существования. В этом случае в «симфонии настроения» произведения органично звучит элегическая «нота», воспроизводящая цепь мимолетных состояний внутренней жизни личности. Элегическое чувство «живой грусти об исчезнувшем», причастности Всеединому Многоликому (а потому Безличному) Бытию, хронотоп уединения и странничества (В. С. Тюпа) «дробят» время на неповторимость мгновений, вписанных в картину общего жизнесложения (неслучайно один из наиболее известных сборников Э. Мижита называется «Расколотый миг» (2011).

В стихотворении «Мысль» (цикл «Глас тишины», 2011), организованном по принципу диады трехстиший, - антиномия внутреннего и внешнего «Я», в единстве которых рождается Слово.

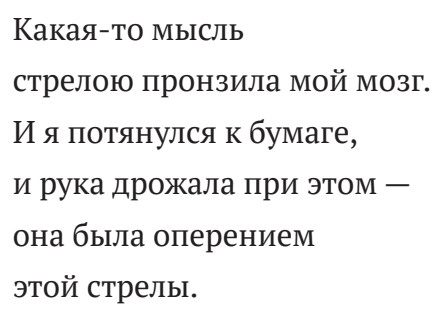

Образ стрелы синкретичен: стреле уподобляется мысль как интенция сверхчеловеческого порядка, стрела метафорически «вбирает» самого лирического героя, становится символом направленной творческой энергии, переданной его руке - руке человека Созидающего. За «мыслью-стрелой» (а сравнение в данном случае указывает на «орудийность») незримо встает фигура, пославшего ее - фигура божественного Охотника, поразившего свою цель - Поэта. Поэт, пронзенный стрелой мысли, сам претерпевает трансформацию, превращаясь в орудие «божественной охоты»: теперь ему предстоит стать стрелой, «летящим» посредником между божественным и человеческим. Поэт - стрела, посланная силой высшего порядка, и ей надлежит найти свою цель - сознание соприкоснувшегося с его Словом.

Стрела в тувинской культуре наделена сакральной символикой. Как отмечает М. Б. Кенин-Лопсан, священная стрела (ыдык оък), на мифопоэтическом уровне связанная с Верхним миром (Небом), посредник между мирами, уподобленный солнечному лучу; это атрибут, свидетельствующий о контакте человека с божественной сущностью (Кенин-Лопсан, 2006: 46). Стрела в мировоззрении тувинцев символически соотносима с человеческой судьбой: траектория ее полета сравнивается с индивидуальной жизнью человека, которая дарована ему свыше. Тот, кто «выбирает цель и натягивает тетиву», делает человека избранником своей воли, и поэт не может избежать своей избранности. Он - медиатор и в то же время инструмент в извечной космогонии. В приведенном стихотворении разыгрывается, по сути, акт соприкосновения человека с Демиургом - и в семантической полноте глагола, описывающего состояние лирического героя («рука дрожала»), передано ощущение наивысшей степени его душевного волнения и осознания великой ответственности за дарованное ему Слово.

Стихи для Мижита - это Зов; это Служение; это сила, гармонизирующая мир. В стихотворении «Спасение» (Цикл «Мой одинокий зов», 2011) Мижит пишет:

$\begin{array}{ll}\text { Я молитвенным бдением } & \\ \text { стихов, } & \text { черным } \\ \text { как монах, } & \text { бессмысленным оком } \\ \text { спасаюсь от хаоса мрака, } & \text { с тусклым, } \\ \text { алчно глядящего } & \text { как у мертвеца, } \\ \text { мне прямо в душу } & \text { зрачком - луной... }\end{array}$


В «молитвенных бдениях стихов» - буддистская идея самопознания, органично переплетенная с дуальным архетипом Хаоса-Гармонии, который является базисным для мифологического мышления древних народов. Неслучайно лирический герой сравнивает себя с монахом.

Согласно традиционным воззрениям буддизма, в процессе следования своему Срединному пути посвященный (монах) осмысливает четыре «благородных истины». Первая из них - страдание (физическое и экзистенциальное). Оно проистекает из осознания собственной смертности и непостоянства всех явлений. Экзистенциальная тревога рождается из жажды и невежества (вторая истина), которые можно преодолеть с помощью знания (третья истина). Страдания преодолимы, если прилагать каждодневные усилия («бдения» у Мижита) в работе над собой: практиковать сосредоточенность, осознанность, правильную речь и др.

Таким образом, Поэт - существо в высшей степени сознательное. Творчество для него - служение, призванное противостоять Хаосу (отметим, что образ Хаоса связан с мотивами ночи, смерти и бессмысленности через комплекс поэтических характеристик). Поэт - избранный (и посвященный), а поэзия его приравнена к Служению.

Интересно отношение Бахыта Каирбекова к Душе и к Поэзии, выраженное в гениальном трехстишии (1976):

\section{Когда в степи моей \\ Умолкнут кузнечики, \\ Я умру.}

Казалось бы, во внешней форме этой лирической миниатюры (которая по интенсификации мысли, «обрывающейся» в силлабическом строении последней строки, так напоминает ожук дажы), ни слова не сказано ни о душе, ни о поэзии. Но об ином свидетельствуют символы стихотворения - аккумулированные в них сверхсмыслы открывают исследователю пути многочисленных амплификаций исходного текста.

Исследователь М. Сомадай отмечает, что данным трехстишием поэт пророчит себе бессмертие: «Спрашивается: когда они умолкнут? Разве что с кончиной мира» (Сомадай, 2014: 379). В масштабе надвременья жизнь степи непрерывна и вечна; циклы жизни, смерти и воскрешения сменяют друг друга в чередовании фаз, периодов и эпох. Покуда жива степь, наполненная вибрациями бесчисленных звуков, жив человек, воспринимающий себя частью этого мира. И здесь необходимо отметить, что анимизм как особая форма мироощущения кочевника (актуальная и сегодня) позволяла ему осмысливать себя как живой элемент великой Природы, своей Родины и всего мироздания. Степь - колыбель кочевника и его последнее пристанище. По свидетельству Ж. К. Каракозовой и М. Ш. Хасанова, в представлениях древних тюрков душа человека бессмертна, пока существует земля его рождения, жизни и смерти, а память предков не позволяет ей раствориться в безвременье (Каракозова, Хасанов, 2001). Отсюда - метонимическое единство степи и ее народа (выраженное в безэквивалентном для русского языкового сознания концепте «Эль»), их онтологическая неразрывность. Пока живет Степь и населяющий ее народ, жив поэт.

Но и внутри этого «большого времени» (М. М. Бахтин) существуют свои циклы: времена года сменяют друг друга в круговом вращении вечности, и кузнечики умолкают с наступлением холодов, чтобы продолжить свое стрекотание в период воскрешения природы и обновления мира. Лирический герой осознает, что смерть на его духовном пути неизбежна - как осознает и то, что она не конечна, что ему предстоит не единожды пройти цикл умирания и воскрешения. Глагол «умолкнуть», в отличие от однокоренного ему «замолкнуть», сигнализирует о временном прерывании звука: об этом свидетельствуют устойчивые в русском языке сочетания «умолкнуть на время» (ср. «замолкнуть навеки», «замолчать навсегда»). Цикл жизни-смерти-воскрешения поэта - своего рода череда творческих инициаций, сопряженных с метаморфозами Души и поэтического дара. Для творческой личности человека созидающего подобные трансформации витально оправданны и жизненно необходимы.

Степь для Б. Кирбекова - не только пространство географического порядка, связанное с историей и культурой казахского народа; это «внутренняя территория» духа с особым онтологическим укладом и уникальной телеологией. И если наше наблюдение верно, рождается еще одна, дополнительная интерпретация стихотворения, связанная с образом кузнечика.

Зададимся вопросом: почему кузнечику отведена в произведении роль своеобразного «регулятора» жизни? Оттого ли, что кузнечик как существо, способное издавать звуки (вибрации), становится 
символом «звучания жизни»? Отчасти так. Культура кочевника, как пишет Г. Гачев, это культура «слуховая» в противовес культуре оседлой - «зрительной» (Гачев, 1999: 13). И Слово - тоже вибрация, колебание энергий Вселенной. В культуре скифов, как пишет Д. С. Раевский, кузнечик связан с порождающими функциями природы и божествами земли; он концептуализирует идею умирания и возрождения, которой подвластны все живые существа (Раевский, 2006: 192).

Однако в мировой культурной традиции за образом кузнечика закреплены дополнительные мифопоэтические смыслы. Так, в литературе Древней Греции кузнечик - образ, связанный с Фебом и Музами. В широкий культурный контекст он введен Анакреонтом как мифологема поэта-цикады, возлюбленного Муз, посредника между мирами. Лирическая миниатюра Анакреонта стала импульсом для многочисленных интертекстуальных трансформаций, в частности, в русскоязычной литературе: в стихотворениях А. Кантемира, М. Ломоносова, Г. Державина, П. Андреева, Н. Гнедича, В. Хлебникова, О. Мандельштама, Вяч. Иванова, З. Гиппиус, Н. Заболоцкого, А. Тарковского, Б. Кенжеева, Б. Окуджавы и др. образ кузнечика атрибутирован многочисленными над-смыслами. Так, в стихотворении М. Ломоносова «Стихи, сочиненныя по дороге в Петергоф, когда я в 1761 году ехал просить о подписании привилегии для Академии, быв много раз прежде за тем же», кузнечик воплощает мечту о свободе поэта, который «не просит ни о чем, не должен никому». В. Хлебников возвращает указанному образу изначальную сакральность, одический пафос. А. Тарковский в своей «Загадке с разгадкой» называет кузнечика «внуком Хирона», «полувсадником-полуконем»: действительно, в античной поэтической традиции кузнечик - существо химерическое, нередко уподобляемое кентавру (символизирующему знание) и пегасу, олицетворяющему вдохновение. В поэтическом универсуме Б. Окуджавы кузнечик актуализирует идею о самоотверженном служении поэта людям.

Исследования образа кузнечика в мировой и русской литературе довольно обширны. Нас в данном случае интересует инвариант, формирующийся из многочисленного корпуса текстов (отметим, что в поэтическом корпусе русского национального языка за лексемой «кузнечик» установлено 142 вхождения). Инвариантное же значение этой мифологемы соотносится не только с идеей умираниявоскрешения, но и с мотивами поэта, поэзии и поэтического служения людям.

Таким образом, стихотворение Б. Каирбекова можно интерпретировать и так: «Когда в моей душе умолкнут стихи, я умру». И в этом смысле лирический герой провозглашает свою роль на земле - роль Поэта, творящего мир.

Стихи пишутся кровью. В стихотворении «Если сердце твое кровоточит» (2003) Каирбеков говорит:

Если сердце твое кровоточит,

Пиши.

В лавке торговца

Этих чернил

Тебе не купить.

Поэзия становится для Каирбекова не только служением, но и жертвой, которую он добровольно приносит миру. Неслучайно это кровь сердца: жизнь сердца, как и жизнь стихотворения, подчинена закону ритма.

И для Мижита, и для Каирбекова творчество - единственно возможный способ существования. Такова внутренняя «конституция» поэтической души; каждое стихотворение, фиксирующее поэтическую мысль, становится актом осознания собственной сверхзадачи: противостоять Хаосу внутреннего и внешнего бытия гармонизирующей силой слова.

Для Мижита поэтическая мысль есть удел избранности, который нельзя «отринуть»: путь поэта это путь священной стрелы; это кропотливая работа души, «бдения», которыми он спасается от хаоса мрака. Для Каирбекова быть поэтом - значит, жить, умирая и воскресая с каждым стихотворением, и не мыслить своего существования как-либо иначе: если умолкнуть стихи, умолкнет душа. В одном из своих эссе Каирбеков пишет: «Мне кажется, стихи - это моя душа» ${ }^{1}$.

Для обоих поэтов творчество - не просто попытка осмыслить мир, но сам акт его (мира) создания.

\footnotetext{
${ }^{1}$ Каирбеков Б. Г. Далекие и близкие: избранные переводы. Астана: Аударма, 2012. 288 с. С. 4.
} 


\section{Особенности хронотопа}

Каков этот мир? И для Э. Мижита, и для Б. Каирбекова сакральным жизненным пространством является степь - родина предков.

В циклах верлибров «Бусинки столетий» и «Время моей земли» (2006) Э. Мижит воссоздает грандиозную в своем масштабе картину жизни степи, существующей по своим внутренним законам. Показательно, что жанром цикла избран верлибр - свободный стих, отличающийся нерегламентированной ритмикой, отсутствием обязательного изосиллабизма и регулярной строфики. При этом важным организационным компонентом стихотворения остается повтор (на лексико-синтаксическом уровне это, например, анафора, на интонационном - прием силлабической симметрии, который, тем не менее, факультативен). Как отмечает Л. С. Дампилова, повторяющаяся интонация - один из базовых приемов тюркско-монгольского стихосложения, чем, возможно, и обусловлен выбор Э. Мижитом верлибра как формы стихосложения, близкой национальным структурам (Дампилова, 2015: 198).

Каждая строфа цикла «Бусинки столетий» начинается анафорой «здесь», указывающей на разворачивающееся место действа (не действия) национальной истории - Туву, где само Время возделывает душу земли и народа, а степи «слегка рыжеваты» от «запекшейся крови» закатов, народов, эпох и империй, умирающих и воскресающих подобно травам. Земля и небо, люди и цветы - суть одно в круговороте жизни, и седые «от древности наших преданий» туманы превращаются в «росы» нового смысла, приветствующие «новую зарю». Вера в единство природы и человека, их бесконечное со-бытие выражена в сравнении людей с цветами, настолько яркими от «радужных душ» людей, живущих на этой земле «от начала и центра времен до бесконечно вдаль уходящего их горизонта», что «небесные силы» принимают одно за другое.

Время у Э. Мижита уподоблено вольному необъезженному табуну, что несется во весь опор сквозь столетия и эпохи; оно динамично и неукротимо, подвижно и быстротечно. Метафора «табун» (т. е. множество лошадей) глубоко символична: по мнению А. М. Соян, образ лошади в поэтическом мире Э. Мижита знаменует идею свободы; более того, лошадь воплощает такие положительные черты национального характера, как добродетель, гордость, независимость (Соян, 2018). Время, табуном несущееся сквозь столетия, обретает дополнительную семантику «благостного» развития народа: тувинский этнос остается свободным, не терпящим несправедливости, верным священным заветам предков. Но оно же - время - задумчиво-длительно, как «взгляд старого табунщика», в чьих глазах «сверкают наконечники стрел», подобные звездам (символ изначальности и бесконечности мира), летящие из необозримой глубины веков.

Время у Мижита циклично: поэт сравнивает его с полетом орла «по спирали эпох», со свернутым свитком священной сутры. Отметим, что образ орла в поэтическом универсуме Э. Мижита также символичен. Данный орнитоморфный символ связан с идеей божественного покровительства этносу (орел - царь всех птиц, могучий защитник добра, противоборствующий силам Хаоса).

Время в цикле «Бусинки столетий» одухотворено присутствием в этом мире Человека, в чьей груди оно «зреет», как песня, чтобы вырваться из нее птицей (душой):

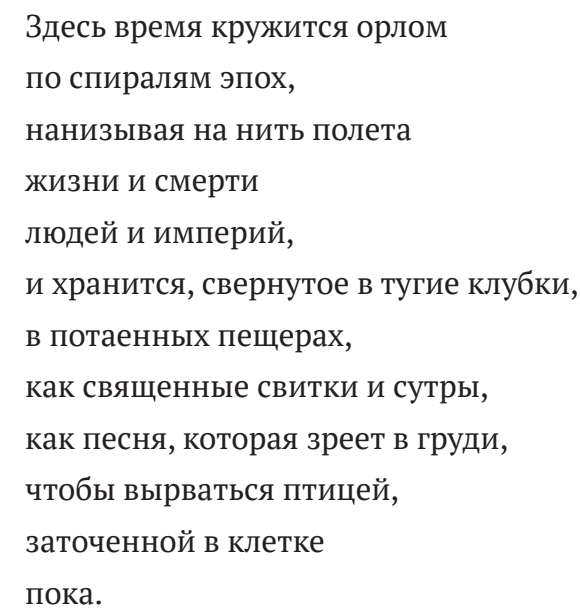

Песня - космогонический акт Первотворения, обязательный элемент великого шаманского Камлания; оттого у времени долгое, «как у шаманского бубна», эхо, отдающееся в настоящем. Еще один 
символ времени у Мижита - горделивый верблюд, что жует и жует «все легенды, сны и воспоминания трав и ветров». Верблюд в мировосприятии кочевника - олицетворение Вселенной: в его образе божественно проявлены черты всех населяющих землю животных. Вновь и вновь перемалывает Вечность людские эпохи, и время, уставшее от «повинности» идти только прямо, «играет в прятки с самим собой»: оно расслаивается в потоки, позволяя человеку жить «во всех временах одновременно» в священном месте, названном Тувой:

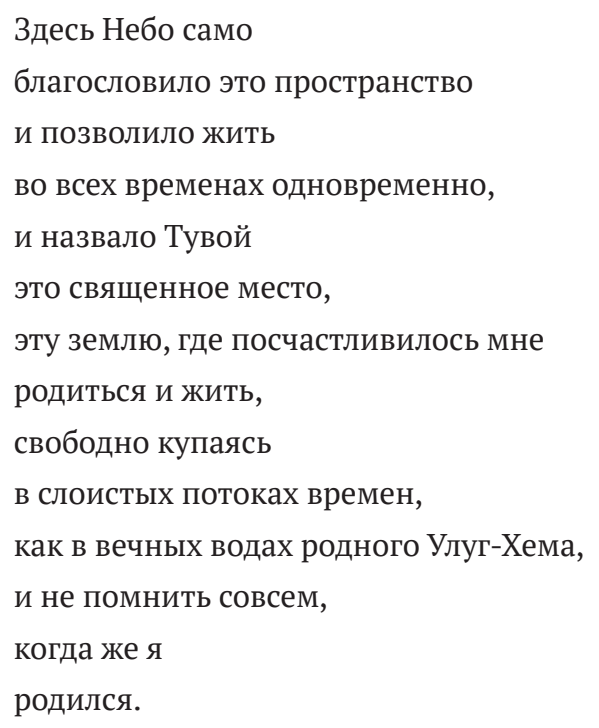

Тува для Мижита - сакральное пространство, место, где явлен Бог. Заглавие одного из стихотворений - «Место, где Бог...» (2006) - семантически сильная позиция текста, эксплицирующая отношение поэта к родному краю. В стихотворении ярко выражена категория адресности: поэт обращается к Туве в модусе проникновенной интимности, который обеспечивает двуплановость восприятия: Тувы как национального космоса, древнего, как время, и Тувы как глубоко личного, сокровенного пространства жизни лирического героя:

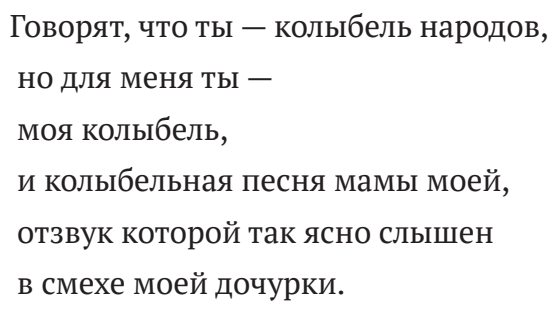

Уже в первой строфе образ Тувы коррелирует с материнским началом, с символом колыбели и колыбельной песни - древнейшего фольклорного жанра, несущего магическую охранную функцию и призванного уберечь ребенка от воздействия враждебных сил. Колыбельная песня, как правило, содержит различные уменьшительно-ласкательные обращения к ребенку, ласковые просьбы «успокоиться, уснуть», пожелания, перечисления добрых и злых сил, способных сохранить ребенка или, напротив, навредить ему. Это часть материнского фольклора, которая впервые вводит человека в интонационный мир этнической культуры. Она же знакомит ребенка с организацией социального пространства, в котором ему предстоит жить и созидать. Колыбельная, отзвуком слышащаяся лирическому герою в смехе дочурки, становится и символом преемственности стихийного, самобытного знания.

Во второй строфе стихотворения пространство и время расширяются, соединяясь в душе человека: Говорят, что ты проста, как загадка, но для меня ты таинственный звук каргыраа, звук, в котором Небо с Землей ищут друг друга, тоскуя, и встречаются здесь в душе человека. 
Для лирического героя Тува таинственна, как каргыраа - древнейший вид горлового пения, которое исполняется на низких частотах. В горловом пении отражено музыкально-специфическое мышление народа, стремящегося передать жизнь природы путем проникновения в ее сущность. Это не мимезис как таковой, но углубление в суть явления, попытка слиться с ним в творческом акте. Существует мнение, что стиль каргыраа возник среди тувинцев-верблюдоводов как подражание плачу верблюдицы, потерявшей верблюжонка. Для него характерно хрипение. Неслучайно в трагическом звучании каргыраа лирический герой слышит тоску Неба и Земли, вечно стремящихся друг к другу.

Для него Тува - не древность, уже не помнящая о прошлом, но сундук предков, полный мечтаний о прошлом и будущем; суровая нежность стихов; бесконечная песня, в которой он сам - лишь недолгая тихая-тихая нотка. У героя - своя Тува, не податливая, как масло, но многослойный и острый, как слово, меч, выкованный прадедом-кузнецом.

В последней строфе стихотворения Мижит пишет:

Говорят, что ты

всего лишь географический центр

Азиатского материка,

но для меня ты -

центр Земли и Вселенной,

средоточие духа моего

древнего народа,

Тува моя, ты - то самое место,

место, где Бог

находит и видит меня

насквозь.

В стихотворениях «Попытка отгадки» и «Здесь не надо искать» (2004) священная Тува обретает новые поэтические характеристики: это пространство великой тишины Земли, ждущее первого звука; место, ожидающее часа, когда сердца людей откроются друг другу; кипящий котел, испытывающий цену человеческой жизни, любви, борьбы; кольца вечности, по которым кружат вольные орлы поднебесья, поющие песнь о свободе. Здесь песчинками на дне океана спят все времена, здесь мифы рождаются, как облака, и растут, как трава. Это пространство явленное и незримое, на земных языках именуемое Тувой. И каждый ребенок, и каждый старик - это вечный ребенок и предок времени. Время в стихотворениях нелинейно; оно движется по спирали, повторяясь на каждом ее витке в новом - и все же в прежнем -своем качестве. Такова его диалектика.

Ч. К. Ламажаа, исследующая феномен времени в тувинской культуре, упоминает о так называемом «степном времени» и, адаптируя концепцию Р. Льюиса применительно к исследуемой проблематике, отмечает, что для народов Востока «время не линейно, оно не привязано к людям или событиям, оно циклично. Каждый день солнце встает и садится, одно время года следует за другим, небесные тела совершают свое круговращение, люди стареют и умирают, но их дети повторяют все сначала» (Ламажаa, 2018: 11).

Как пишут Ж. К. Каракозова и М. Ш. Хасанов, время в национальном мировосприятии казахов также циклично, подчинено сменяющим друг друга ритмам жизни-смерти-жизни, трансформативно: Хаос становится Гармонией, Гармония, разрушаясь, возвращается к Хаосу, чтобы воплотиться в новом качестве. Это детерминировано историческим ареалом обитания кочевых народов - степью. «В степи была очевидной природа Божества, имеющего окружность везде, и беспредельность пространства становилась качеством этого божества. Вся земля была для кочевника вращающимся шаром, потому что он кочевал по кругу в семьсот километров от джайляу (летовки) к куздеу (осенней точке откочевки), от куздеу к кыстау (зимнему месту жилья), от кыстау к коктеу (весеннему) и от коктеу снова к джайляу. Законы кругового движения дали кочевникам-казахам первые представления о мире» (Каракозова, Хасанов, 2001: 106).

Б. Каирбеков, воспринимающий себя «степенным» сыном своего народа (языковая игра, когда деривация прилагательного намеренно омонимична и намекает не на исходную в словообразовательном ряду лексему «степень», но на «степь» как альтернативную внутреннюю форму слова), видит в образе степи свою нерасторжимую связь с космосом родной культуры, в который он возвращается вновь и вновь («И эта даль бескрайняя в степях», 2012): 
И эта даль бескрайняя в степях,

Вся эта ширь и высь - и есть мой дом.

Высоких не поставить мне дверей.

Чтоб каждый мог уверенно входить,

Храня в себе степенность, стать свою,

Степного неба помня высоту,

Чтоб в доме этом петь, как здесь поют

Караторгаи, славя чистоту

Воздушных струй и даль степных дорог,

Домбры сказанья, пену кумыса

Всё это - мне дарованное впрок

И есть земля моя, мой дом, мой сад.

Хронотоп бесконечного простора, движения-кочевья как избранного народом способа существования (хронотоп пути, по формулировке В. Тюпы), ощущения со-причастности между людьми «единого племени» становятся смысловыми доминантами текста. В степи каждый человек - путник и гость; оттого невозможно отгородить себя от мира высокой дверью (полог юрты, напротив, всегда открыт для степного гостя): каждый человек, помнящий высоту степного неба и сказания предков, вкусивший молоко степной кобылицы (кумыс), есть часть одного макрокосма. Степь для лирического героя - дом, а люди этой степи - не только его народ, но и его семья, великие номады, кочующие из прошлого в настоящее в непрерывном круге времени. И сам лирический герой - кочевник, «Перелётная птица, кочевник, кентавр, /В ладу лишь с копытами, /C крыльями, /С пылью дорог!» Необъятный простор ему жизненно необходим; в дневниковых записях Б. Каирбеков отмечает, что взгляд, направленный в бескрайнюю даль, мирит человека с пространством. Если же взгляд упирается в стену, возникает чувство клетки - ощущение тесноты, духоты, никчемности и пигмейства (Кремер, 2010: 152).

Следующее стихотворение, построенное по принципу триады трехстиший (не можем не отметить здесь связи с тувинским жанром ожук дажы), генетически восходит к казахскому народному жанру толгау - философскому размышлению, для которого характерно единоначалие (анафора), лаконичность и афористичность каждой строки, акцентированное, идейно-нагруженное завершение (зачастую актуализированное в форме риторического вопроса). Толгау - жанр песенный; изначально ему присуще «круговое вращение», обыгрывание заданной поэтом темы. Формула круга -обязательное условие казахского песенного жанра: раз за разом возвращаясь к «ядру» своего размышления, кюйши (певец, исполняющий свои произведения на домбре) находит новые оттенки смысла, культурные ассоциации, усложняющие главную тему его творческого послания. Кюйши в казахской культуре наследник древнего знания, восходящего к шаманизму (неслучайно великим шаманом считали родоначальника песенного искусства Коркыта, который изобрел первый музыкальный инструмент кочевника - кобыз. Кобыз был изготовлен Коркытом из кожи священной Верблюдицы и, по преданию, помог старцу одолеть саму Смерть).

В стихотворении «Степь - многотравный простор» (2012) реконструирован космос национальной культуры:

Степь - многотравный простор,

Горизонты походов травы.

Степь - ствол необъятный дыхания земли.

Степь - песен гортань,

Столба позвоночного выход.

Свирели земное отверстие звучное.

Как же мне славить тебя, мой космический Век?

Что мне игрушки твои - если я позабыл

Своё знанье травы, и степей, и небесного древа?

Первые две строфы несут в себе уникальные коды кочевой культуры. Многотравный простор на уровне поэтической ассоциации коррелирует с устойчивым казахским эпитетом «ала» («пестрый», 
«многоцветный») - сакральным цветом, несущим в мировосприятии казахов символику благостности, изобилия, дара богов.

Цветосимволика в языковой картине мира казахов связана с тенгрианством: священными считаются цвета кок («голубой»), олицетворяющий вечное Небо (Тенгри), ак (белый»), символизирующий чистоту божественного, сары («желтый»), восходящий к культу земли, и ала («пестрый», «многоцветный»), связанный с изобилием и щедростью мира.

Степь - земля, благословленная Богами. Примечательно, что поэт называет ее «горизонтом походов травы» - не восходов, которые указывали бы на рост земного стебля. Трава здесь уподобляется кочевнику, и не просто кочевнику - самому степному воинству (слово «поход» означает, в частности, завоевательное шествие войска). За образом «походов травы» рождается образ великой армии кочевников-предков, покорявших огромные степные территории. «Необъятный ствол дыхания земли» мифопоэтическая реализация несущей оси мироздания, мирового древа, соединяющего миры Небо, Срединную землю «сынов человеческих» и подземный мир. Эта ось пронизывает и самого человека («столба позвоночного выход»), триединого существа, обладающего тремя душами - рухижан, ет-жан, шыбыл-жан Без священного знания степей, травы, небесного древа, без корневой связи с родной культурой «игрушки Космического века» - атрибуты пустого, ненужного существования существования «лишнего человека». А потому вернуться к «огню родного очага» для лирического героя значит вернуться к истокам «живой жизни», возрождающей и питающей его душу.

Воссоздавая в своих стихотворениях космос национальной культуры, Э. Мижит и Б. Каирбеков обращаются к концептам, имеющим для них принципиальное аксиологическое наполнение. Для Э. Мижита это Тува, «место, где Бог» и где человек существует во всех эпохах одновременно. Хронотоп рассмотренных нами стихотворений многослоен; поэт уподобляет время великой спирали, священной сутре, бегу неукротимого табуна. Цикличность изображаемого времени генерирует в восприятии читателя особую категорию в его (времени) осмыслении: Панхронос, надвременье, что характерно для миросозерцания кочевых народов. Это отличительная черта и для поэзии Каирбекова, в которой создается авторская модель национального бытия - Великая Степь. Степь Каирбекова, помнящая предков, безгранично-вольная - это пространство жизнесложения этноса и лирического героя как его представителя.

\section{Лирический субъект}

Кто он, лирический субъект поэтического космоса Э. Мижита и Б. Каирбекова?

Он многолик, это, словами Дж. Кэмпбелла, «тысячеликий герой», который отправляется в странствие, влекомый Зовом своей судьбы (Кэмпбелл, 2017). Эта тема заслуживает отдельного исследования. Отметим лишь в общих чертах, что в реконструируемых образах лирического героя Э. Мижита и Б. Каирбекова намечены специфические «культурные маски» (Р. Кайюа) Баксы (Шамана), Охотника, Кочевника, Батыра, Дервиша.

Так, лирический герой Э. Мижита - человек, постоянно пребывающий в нескольких мирах одновременно. В стихотворениях цикла «Сквозь себя» (2011) герой, уставший от «обыденных дел и слов» и попыток поймать «за хвост ускользающих ящериц мгновений», отправляется в таинственный мир сновидений - мир завораживающий и непостижимый. Он пребывает в предвкушении «удачной охоты», он сам - великий Охотник, ускользающий из лап «кровожадных драконов», и в этом смысле образ его восходит к героическому тувинскому эпосу: «В образах эпических богатырей прослеживаются генетические связи с культурными героями, первопредками: самый тип богатыря-героя, наделенного сверхчеловеческими, фантастическими, шаманскими качествами, имеет мифологические корни. Деяния эпических богатырей практически сводятся к одному - борьбе с чудовищами» (Мижит, 2010: Электр. ресурс). Герою предстоит «поймать» невиданное существо, находясь на границе яви и сна:

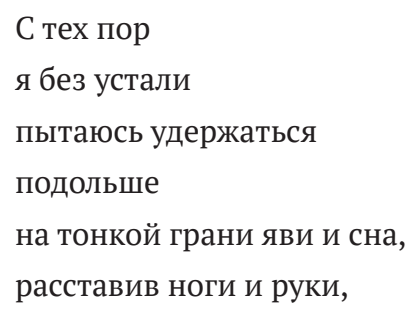

готовый на равных

встретить лицом к лицу...

Кого?

Вот поймаю -

там будет видно. 
Эта космическая схватка - залог обретения нового знания и рождения нового мира. Как отмечает Э. Мижит в своем исследовании космологии в тувинском героическом эпосе, эпизод убийства героем чудовища рекуррентен. Когда Кара-Когел убивает огромное, с таежный хребет, чудовище, из внутренностей его выходят люди разных племен, которые вновь могут видеть солнце и благословляют своего спасителя. В иных случаях тело поверженного врага становится священным местом нового селения (там же). Охотник-батыр, открывший «солнце» своему народу - реализация священной миссии поэта, дарующего людям огонь нового знания.

О вечной, вновь и вновь повторяющейся схватке с чудовищем пишет и Б. Каирбеков («Все стало на свои места», 2003):

\author{
Все стало на свои места. \\ Дракон проголодался. \\ Конь оседлан. \\ Все начинается, увы, не с чистого листа. \\ Лишь Свиток длится... \\ Вот в чем подлость.
}

Герой Каирбекова - Батыр, готовый сразиться с Драконом не единожды. Это извечное противостояние Гармонии и Хаоса, Света и Тьмы, и поэт в этом противостоянии становится Воином, оберегающим мироздание. Такова его извечная ноша. Поэт, по формулировке Цветаевой - «утысячеренный человек», и в других стихотворениях он предстает читателю и как Дервиш (стихотворение «Асатаяк», 2003); Асатаяк - посох странствующего дервиша), и как Перевозчик (стихотворение «Перевозчик», 2003), где герой - посредник между мирами, бесконечно переправляющий людей из одного пространства физического - за трансцендентальную границу бытия).

Лирический субъект стихотворений Э. Мижита и Б. Каирбекова - это, в первую очередь, поэт, гармонией творящий мир. Выступая против Хаоса (а его проявления у обоих поэтов схожи: это суетливое время, разрозненность людей, эмпатическая резистентность общества, бессмысленность и «тщета» существования, оторванного от родной почвы), лирический герой воплощается каждый раз в новом культурном качестве. Так, одна из культурных масок героя у Мижита - архаическая маска Охотника и Батыра, готового сразиться с Чудовищем. Находясь на границе яви и сна, лирический герой Мижита уподобляется шаману, путешествующему между мирами. Подобные функции несет и лирический герой Б. Каирбекова, вечный кочевник, Батыр и одинокий путник в поисках истины.

\title{
Заключение
}

В рамках данной статьи мы лишь заглянули «в замочную скважину мира» (Б. Каирбеков) би- и транслингвальных поэтов, творящих на русском языке. Поэтический космос Э. Мижита и Б. Каирбекова неисчерпаем и требует дальнейших исследований, потому что каждое слово креативного текста арена встречи энергий: языковых, культурных, философских. Мы попытались показать, как сквозь русскоязычное слово «просвечивает» иноязыковое бытие. Однако не всегда культурный пласт в палимпсесте художественного текста наличествует «вещно»: отдельные русскоязычные стихотворения Э. Мижита и Б. Каирбекова не позволяют реконструировать элементы «исходной культуры»: подчиненные логике языка-посредника, они обретают нейтральный культурный статус, и эта проблема требует отдельного пристального внимания.

Русскоязычие - доминирующая транслингвальная практика на территории постсоветского пространства. В данном случае предполагается, что текст «звучит, как русский», но транслирует вовне нерусское видение мира. Сама языковая идентичность авторов-билингвов усложнена за счет их одновременного существования в нескольких лингвистических измерениях. Если языковая личность представляет собой единство вербально-семантического, концептуального и прагматического комплексов, то билингвальная языковая личность, следовательно, «удваивается», трансформируясь в интегральное пространство языковых ресурсов, которые неизменно проявлены в продуктах ее речевой деятельности.

В процессе литературоведческого анализа мы выявили, что транслингвальному поэтическому тексту присущи определенные свойства как на уровне архитектоники, так и на уровне отдельных языковых элементов: 
- наличие своеобразной мифотектоники, когда автор апеллирует к генетическим кодам исходной лингвокультуры (жанрам, архетипам, мотивам и т. д.). Так, Э. Мижит обращается к традиционному тувинскому жанру ожук дажы, творчески приспосабливая его к своим художественным задачам. Поэт вводит в тувинскую литературу жанр верлибра, близкий по своему силлабическому и ритмическому строю поэтическим формам тувинской культуры (например, шаманским песнопениям). Жанры, избираемые Б. Каирбековым, также восходят к традиционным формам казахского этноса. В первую очередь, это жанр толгау, философское размышление о времени, пространстве и месте человека в мире;

- хронотоп стихотворений Э. Мижита и Б. Каирбекова - это сопряжение безграничного пространства и бесконечного времени, обусловленное характерным для кочевой модели мира цикличностью. Если местом действия является степь (ширь, даль), то время начинает двигаться «по спирали», расслаивается, становится многомерным: в стихотворениях Э. Мижита оно уподобляется парящему в небе орлу, неукротимому табуну, горделивому верблюду, потокам вечности. Время у Б. Каирбекова также циклично, связано с чередованием ритмов жизни-смерти-жизни, воплощено в образах-символах кузнечика, травы, свитка (отметим, что у Мижита - это сутра). Пространство и время в творчестве обоих поэтов одухотворено, связано с природой и населяющими ее существами, живыми и «неживыми». Анимистические представления о мире, лежащие в основе мировоззрения обоих поэтов, являются традиционными для кочевой и шаманской культуры;

- лирический субъект творчества Э. Мижита имеет черты специфических «культурных масок»: это шаман, монах, батыр. Каждая из культурных ипостасей героя связана с гармонизирующей силой творчества, способного преобразить мир. Показательно, что культурные маски лирических субъектов Э. Мижита и Б. Каирбекова во многом совпадают: в поэзии казахстанского писателя репрезентациями лирического героя становятся образы номада, баксы, батыра, дервиша. Творчество становится для поэта актом Космогонии.

Для обоих авторов Поэзия есть великое служение - сосредоточенное и самоотверженное.

Дальнейшие лингвистические исследования творчества транслингвальных писателей, в частности, Э. Мижита и Б. Каирбекова, требуют новых подходов, в основе которых лежит междисциплинарный синтез; поиска новых путей осмысления и описания созданных ими произведений. Эта проблема имеет векторный характер; она нуждается в привлечении комплексной парадигматики общегуманитарного знания, позволяющей исследователю работать на нескольких уровнях: лингвокультурологическом, психолингвистическом, лингвокогнитивном, философском. И в этом смысле русскоязычие - не только перспективная художественная практика, но и эпистемологический вызов, стоящий перед «лингвистикой третьего тысячелетия».

\section{СПИСОК ЛИТЕРАТУРЫ}

Бадиков, В. В. (2003) Стенография души // Каирбеков, Б. Дневник. Алматы : Интерпринт. 224 с. С. 3-4.

Бахтикиреева, У. М. (2009) Творческая билингвальная личность (особенности русского текста автора тюркского происхождения). Астана : ЦБО и МИ. 259 с.

Бахтикиреева, У. М., Шагимгереева, Б. Е. (2020) Языковое бытие творческой личности: Бахыт Каирбеков // Социальные и гуманитарные науки на Дальнем Востоке. Т. XVII. Вып. 1. С. 83-89.

Вайнрайх, У. (1979) Языковые контакты: Состояние и проблемы исследования. Киев : Вища школа. Изд-во при Киев. ун-те. 263 с.

Гачев, Г. Д. (1999) Национальные образы мира. Евразия - космос кочевника, земледельца и горца. М. : Институт ДИ-ДИК. 368 с.

Дампилова, Л. С. (2014) Мотив двойничества в поэзии Эдуарда Мижита // Сибирский филологический журнал. № 3. С. 158-163.

Дампилова, Л. С. (2015) Феномен билингвизма в современной поэзии народов Сибири // Сибирский филологический журнал. № 3. С. 196-202.

Джуанышбеков, Н. О. (2010) Социальное значение интегрированной литературы // Russian Journal of Education and Psychology. № 3. C. 141-144.

Донгак, У. А. (2020) Новаторство писателя-билингва Эдуарда Мижита (тувинская поэзия) [Электронный ресурс] // Полилингвиальность и транскультурные практики. T. 17. № 4. URL: http://journals.rudn.ru/polylinguality/ issue/view/1367 (дата обращения: 15.09.20). DOI: 10.22363/2618-897X-2020-17-4-4 
Канагараджа, С. (2016) Мультилингвальная педагогика неолиберального времени: расчистка территории и планирование движения вперед // Социальные и гуманитарные науки на Дальнем Востоке. № 2 (50). С. 10-21.

Каракозова, Ж. К., Хасанов, М. Ш. (2001) Космос казахской культуры // Евразия. Вып. 2. С. 106-112.

Кенин-Лопсан, М. Б. (2006) Тыва чоннуң бурунгу ужурлары [Древние традиции тувинцев]. Кызыл : Тувинское книжное издательство. 230 с. (На тув. яз.)

Кошелева, А. Л. (2016) Парадигма образного воплощения и имманентного синтеза категорий «Пространство», «Время» и «Человек» в лирико-философской поэме народного писателя Республики Тыва Э. Мижита «Пируэты мысли» // Филология и культурология: современные проблемы и перспективы развития: сборник материалов 20-й международной научно-практической конференции, (г. Махачкала, 15 мая 2016 г.). Махачкала : Издательство «Апробация». С. 20-24.

Кремер, Е. Н. (2010) Проблемы русско-инонационального билингвизма (языковая и этническая идентичность билингвальной личности) : дисс. ... канд. фил. наук. М. 203 с.

Кэмпбелл, Дж. (2017) Тысячеликий герой. СПб. : Питер. 352 с.

Ламажаa, Ч. К. (2018) Тувинское время и экономическая культура тувинцев // Новые исследования Тувы. № 2. C. 4-21. DOI: https://www.doi.org/10.25178/nit.2018.2.1

Лейдерман, Н. Л. (2005) Постреализм : теоретический очерк. Екатеринбург : УГПУ. 244 с.

Мижит, Л. С. (2007) Триада в тувинской словесности: поэтический жанр ожук дажы : автореф.... канд. фил. наук. Уфа. 23 с.

Мижит, Э. Б. (2010) Тувинская традиционная космология в героическом эпосе [Электронный ресурс] // Новые исследования Тувы, № 1. URL: https:/nit.tuva.asia/nit/article/view/570 (дата обращения: 12.09.2020).

Прошина, 3. Г. (2017) Транслингвизм и его прикладное значение // Вестник Российского университета дружбы народов. Серия: Вопросы образования: языки и специальность. Т. 14. № 2. С. 155-170.

Раевский, Д. С. (2006) Мир скифской культуры. М. : Книга по требованию. 600 с.

Сомадай, М. (2014) Шаманизм без кавычек. Эссе о творчестве Бахыта Каирбекова // Каирбеков Б. Навстречу солнцу. Дневник путешествий. Статьи, эссе. Алматы : Нуракынов. 420 с. С. 379-403.

Соян, А. М. (2018) Образы-символы в поэмах Э. Мижита // Мир науки, культуры, образования. № 6 (73). С. $563-564$.

Томанова, Н. М. (2012) Поэтическая концептосфера Бахыта Каирбекова // Материалы международной научнотеоретической конференции «Актуальные вопросы современной филологии: теоретические проблемы и прикладные аспекты», посвященной 80-летию академика Багизбаевой Маи Михайловны / отв. ред. К. Абдезулы. Алматы : Қазақ университеті. 347 с. С. 182-186.

Тлостанова, М. В. (2004) Жить никогда, писать ниоткуда. Постсоветская литература и эстетика транскультурации. М. : URSS. 412 с.

Тлостанова, М. В. (2006) Транскультурация как новая эпистема эпохи глобализации // Вестник РУДН. Серия Философия. № 2. С. 5-16.

Туманова, А. Б. (2010) Контаминированная языковая картина мира в художественном дискурсе писателябилингва. Алматы : КБТУ. 260 с.

Тюпа, В. И. (2012) Модусы художественности // Введение в литературоведение / отв. ред. Л. В. Чернец. М. : Издательский центр «Академия». 720 с. С. 54-69.

Хугаев, И. С. (2008) Генезис и развитие русскоязычной осетинской литературы. Владикавказ : Ир. 560 с.

Bakhtikireeva, U., Valikova, O., King, J. (2017) Translingualism: Communicative Bridge or “Cultural Bomb”? // RUDN Journal of Language Education and Translingual Practices. № 14 (1). P. 116-121. $175 \mathrm{p}$.

Garcia, O., Wei, L. (2014) Translanguaging: Language, Bilingualism and Education. New York : Palgrave Macmillan.

Kellman, S. G. (2003) Switching languages: translingual authors reflect on their craft. Lincoln ; London : University of Nebraska Press. 339 p.

Kellman, S. G. (2019) Translingual Writers: Introductory Notes // Polylinguality and Transcultural Practices. № 16 (1). P. 9-12. DOI: https://www.doi.org/10.22363/2618-897X-2019-16-1-9-12

Tannenbaum, M., Haim, O. (2007) Journeys to a New Homeland // Journal of Modern Jewish Studies. N. 6 (3). P. $273-287$. DOI: https://www.doi.org/10.1080/14725880701655037

Transcultural identities in Contemporary literature (2013) / I. G. Nordin, J. Hansen, C. Z. Llena (eds). New York : Rodopi. $320 \mathrm{p}$. Дата поступления: 05.10.2020 2.

\section{REFERENCES}

Badikov, V. V. (2003) Stenografiya dushi [Shorthand of the soul]. In: Kairbekov, B. (2003) Dnevnik [Diary]. Almaty, Interprint. 224 p. Pp. 3 - 4. (In Russ.) 
Bakhtikireeva, U. M. (2009) Tvorcheskaya bilingval'naya lichnost' (osobennosti russkogo teksta avtora tyurkskogo proiskhozhdeniya) [Creative bilingual personality: authors of Turkic origin and their texts in Russian]. Astana, CBO i MI. 259 p. (In Russ.)

Bakhtikireeva, U. M. and Shagimgereeva, B. E. (2020) Yazykovoe bytie tvorcheskoi lichnosti: Bahyt Kairbekov [Linguistic existence of a creative person: Bakhyt Kairbekov]. Sotsial'nye i gumanitarnye nauki na Dal'nem Vostoke, issue 18, no 1, pp. 83-89. (In Russ.)

Vainraikh, U. (1979) Yazykovye kontakty: Sostoyanie i problemy Issledovaniya [Languages in contact. Current state and problems of study]. Kiev, Vishcha shkola. Izd-vo pri Kiev. un-te. 263 p. (In Russ.)

Gachev, G. D. (1999) Natsional'nye obrazy mira. Evraziya - kosmos kochevnika, zemledel'tsa i gortsa [Ethnic images of the world. Eurasia as the cosmos of the nomad, farmer and mountaineer]. Moscow, Institut DI-DIK. 368 p. (In Russ.)

Dampilova, L. S. (2014) Motiv dvoinichestva v poezii Eduarda Mizhita [The motive of the doppelganger in the poetry of Eduard Mizhit]. Sibirskii filologicheskii zhurnal, no 3, pp. 158-163. (In Russ.)

Dampilova, L. S. (2015) Fenomen bilingvizma v sovremennoi poezii narodov Sibiri [The phenomenon of bilingualism in modern poetry of the peoples of Siberia]. Sibirskii filologicheskii zhurnal, no 3, pp. 196-202. (In Russ.)

Dzhuanyshbekov, N. O. (2010) Sotsial'noe znachenie integrirovannoi literatury [The social significance of integrated literature]. Russian Journal of Education and Psychology, no. 3, pp. 141-144. (In Russ.)

Dongak, U. A. (2020) Novatorstvo pisatelya-bilingva Eduarda Mizhita (tuvinskaya poeziya) [New poetic methods in the literary imagination of the bilingual writer Eduard Mizhit]. Polilingvial'nost' i transkul'turnye praktiki, vol. 17, no 4 [online] Available at: http://journals.rudn.ru/polylinguality/issue/view/1367 (access date: 15.09.20). (In Russ.) DOI: https://www. doi.org/10.22363/2618-897X-2020-17-4-

Kanagaradzha, S. (2016) Mul'tilingval'naya pedagogika neoliberal'nogo vremeni: raschistka territorii i planirovanie dvizheniya vpered [Multilingual pedagogy in the neoliberal times: clearing the territory and planning forward movement]. Sotsial'nye i gumanitarnye nauki na Dal'nem Vostoke, no. 2 (50), pp. 10-21. (In Russ.)

Karakozova, Zh. K. and Hasanov, M. Sh. (2001) Kosmos kazahskoi kul'tury [The cosmos of Kazakh culture]. Evraziya, no. 2, pp. 106-112. (In Russ.)

Kenin-Lopsan, M. B. (2006) Tyva chonnuң burungu uzhurlary [Ancient traditions of Tuvans]. Kyzyl, Tuvan book publ. 230 p. (In Tyv.)

Kosheleva A.L. (2016) Paradigma obraznogo voploshcheniya i immanentnogo sinteza kategorii "Prostranstvo”, "Vremya" i "Chelovek" v liriko-filosofskoi poeme narodnogo pisatelya Respubliki Tyva E. Mizhita "Piruety mysli” [The paradigm of figurative embodiment and immanent synthesis of the categories of "Space", "Time" and "Man" in the lyric and philosophical poems by the national writer of the Republic of Tuva E. Mizhit "Pirouettes of thought"]. In: Filologiya $i$ kul'turologiya: sovremennye problemy i perspektivy razvitiya [Philology and cultural studies: modern problems and prospects of development]: a collection of materials of the 20th international research and practical conference, (Makhachkala, May 15, 2016). Mahachkala, Aprobatsiya Publ. Pp. 20-24. (In Russ.)

Kremer, E. N. (2010) Problemy russko-inonatsional'nogo bilingvizma (yazykovaya i etnicheskaya identichnost' bilingval'noi lichnosti) [Problems of Russian-international bilingualism (linguistic and ethnic identity of a bilingual person)]. Diss ... Candidate of Philology. Moscow. 203 p. (In Russ.)

Campbell, J. (2017) Tysyachelikii geroi [The hero with a thousand faces]. St. Petersburg, Piter. 352 p. (In Russ.)

Lamazhaa, Ch. K. (2018) Tuvinskoe vremya i ekonomicheskaya kul'tura tuvintsev [“Tuvan time” and economic culture of Tuvans]. New Research of Tuva, no. 2, pp. 4-21. (In Russ.) DOI: https://www.doi.org/10.25178/nit.2018.2.1

Leiderman, N. L. (2005) Postrealizm: teoreticheskiy ocherk [Postrealism: a theoretical overview]. Ekaterinburg, UGPU. 244 p. (In Russ.)

Mizhit, L. S. (2007) Triada v tuvinskoi slovesnosti: poeticheskii zhanr ozhuk dazhy [The triad in Tuvan literature: the ozhuk dazhi genre of poetry]. Abstract of Diss.... Candidate of Philology. Ufa. 23 p. (In Russ.)

Mizhit, E. B. (2010) Tuvinskaya traditsionnaia kosmologiia v geroicheskom epose [Tuvan traditional cosmology in the heroic epic]. New Research of Tuva, no 1. [online] Available at: https://nit.tuva.asia/nit/article/view/570 (access date: 12.09.20.) (In Russ.)

Proshina, Z. G. (2017) Translingvizm i ego prikladnoe znachenie [Translingualism and its application]. Vestnik Rossiiskogo universi-teta druzhby narodov. Seriia: Voprosy obrazovaniia: iazyki i spetsial'nost', vol. 14, no. 2, pp. 155-170. (In Russ.)

Raevskii, D. S. (2006) Mir skifskoi kul'tury [The world of Scythian culture]. Moscow, Kniga po trebovaniyu. 600 p. (In Russ.)

Somadai, M. (2014) Shamanizm bez kavychek. Esse o tvorchestve Bakhyta Kairbekova [Shamanism without quotation marks: An essay on the work of Bakhyt Kairbekov]. In: Kairbekov, B. Navstrechu solntsu. Dnevnik puteshestvii. Stat'i, esse [Towards the sun. Travel diaries, articles and essays]. Almaty, Nurakynov. 420 p. (In Russ.) 
Soyan, A. M. (2018) Obrazy-simvoly v poemakh E. Mizhita [Symbolic imagery in poems by E. Mizhit]. Mir nauki, kul'tury, obrazovaniya, no. 6 (73), pp. 563-564. (In Russ.)

Tomanova, N. M. (2012) Poeticheskaya kontseptosfera Bakhyta Kairbekova [The poetic conceptual sphere of Bakhyt Kairbekov]. In: Materialy mezhdunarodnoi nauchno-teoreticheskoi konferentsii «Aktual'nye voprosy sovremennoi filologii: teoreticheskie problemy i prikladnye aspekty», posvyashchennoi 80-letiyu akademika Bagizbaevoi Mai Mikhailovny [Proceedings of the international research conference "Urgent issues of modern philology: theoretical problems and applied aspects", dedicated to the 80th anniversary of academician Mai Mikhailovna Bagizbayeva]. Ed. by K. Abdezuly. Almaty, Қазақ universiteti. 347 p. Pp. 182-186. (In Russ.)

Tlostanova, M. V. (2004) Zhit' nikogda, pisat' niotkuda. Postsovetskaya literatura i estetika transkul'turatsii [Live never, write from nowhere. Post-Soviet literature and aesthetics of transculturation]. Moscow, URSS. 412 p. (In Russ.)

Tlostanova, M. V. (2006) Transkul'turatsiya kak novaya epistema epokhi globalizatsii [Transculturation as a new episteme of globalization]. Vestnik RUDN. Seriya: Filosofiya, no. 2, pp. 5-16.

Tumanova, A. B. (2010) Kontaminirovannaya yazykovaya kartina mira v hudozhestvennom diskurse pisatelya-bilingva [Contaminated linguistic picture of the world in the artistic discourse of a bilingual writer]. Almaty, KBTU. 260 p. (In Russ.)

Tyupa, V. I. (2012) Modusy hudozhestvennosti [The modes of artistry]. In: Vvedenie v literaturovedenie [Introduction to literary studies]. Ed. by L. V. Chernets. Moscow, Izdatel'skii tsentr «Akademiya». 720 p. Pp. 54-69. (In Russ.)

Hugaev, I. S. (2008) Genezis i razvitie russkoyazychnoi osetinskoi literatury [Genesis and development of Russian-language Ossetian literature]. Vladikavkaz, Ir. 560 p. (In Russ.)

Bakhtikireeva, U., Valikova, O., King, J. (2017) Translingualism: Communicative Bridge or “Cultural Bomb”? RUDN Journal of Language Education and Translingual Practices, no. 14 (1), pp. 116-121. $175 \mathrm{p}$.

Garcia, O. and Wei, L. (2014) Translanguaging: Language, Bilingualism and Education. New York, Palgrave Macmillan.

Kellman, S. G. (2003) Switching languages: translingual authors reflect on their craft. Lincoln and London, University of Nebraska Press. 339 p

Kellman, S. G. (2019). Translingual Writers: Introductory Notes. Polylinguality and Transcultural Practices, no. 16 (1), pp. 9-12. DOI 10.22363/2618-897X-2019-16-1-9-12

Tannenbaum, M. and O. Haim (2007) Journeys to a New Homeland. Journal of Modern Jewish Studies, no. 6 (3), pp. 273-287. DOI: https://www.doi.org/10.1080/14725880701655037

Transcultural identities in Contemporary literature (2013) / I. G. Nordin, J. Hansen and C. Z. Llena (eds). New York, Rodopi. 320 p.

Submission date: 05.10.2020. 